\title{
„Wolne środki” w ustawie o finansach publicznych z perspektywy kompetencji Ministra Finansów
}

\author{
"Spare funds" in the Public Finance Act \\ from the perspective of the powers of the \\ Ministry of Finance
}

Streszczenie. Artykuł podejmuje tematykę instytucji prawa finansów publicznych, jakimi są tzw. wolne środki, poprzez pryzmat kompetencji wykonywanych w tym obszarze przez Ministra Finansów. Autorka dokonuje analizy i oceny obowiązujących przepisów prawa, wskazując na sukcesywne rozszerzanie kompetencji Ministra Finansów w omawianym zakresie. Uprawnienia Ministra Finansów w podjętym obszarze badań przedstawione zostały z kilku perspektyw. $\mathrm{Z}$ jednej strony dokonano analizy uprawnień tego organu do przyjmowania wolnych środków od jednostek sektora finansów publicznych w depozyt, a w konsekwencji wiążących się z tym obowiązków zarządzania nimi. Z drugiej strony wskazano na kompetencje do lokowania wolnych środków budżetowych oraz zarządzania aktywami i pasywami finansowymi na rynku finansowym. Autorka dowodzi, że Minister Finansów występuje w powyższych sytuacjach w odmien- 
nych rolach. Dokonana analiza prowadzi do konstatacji, że ustawa o finansach publicznych nie dość precyzyjnie definiuje i określa oba zakresy działania Ministra Finansów od strony prawnej, pozostawiając pole do elastycznych czy wręcz dyskrecjonalnych działań, koniecznych i uzasadnionych na płaszczyźnie ekonomicznej.

Słowa kluczowe: wolne środki; jednostki sektora finansów publicznych; minister finansów; budżet; dług publiczny.

\begin{abstract}
This article deals with the concept of "spare funds" - an institution of public finance law. The Author decided to look at the above-mentioned institution from the perspective of the powers of the Ministry of Finance. Hence, she analysed and evaluated current regulations, indicating successive broadening of the powers of the Ministry of Finance in this regard. In this article these powers were examined from two points of views. Firstly, the author analysed the Ministry's authority to accept spare funds as a deposit from the public finance sector units and, consequently, to manage them. Secondly, the author indicated the competence of the Ministry to allocate available budgetary funds, as well as to manage financial assets and liabilities on the financial market. The author proves that the roles of the Ministry of Finance in the abovementioned cases differ from each other. The analysis lead to the conclusion that from a legal point of view Public Finance Act does not define precisely the above described competencies of the Ministry of Finance, leaving space for a flexible or even discretionary actions which, in economic terms, are necessary and justified.
\end{abstract}

Keywords: spare funds; units of the public finance sector; Ministry of Finance; budget; public debt.

\title{
1. Wprowadzenie
}

Analiza prawnodogmatyczna instytucji prawa finansów publicznych możliwa jest z wielu perspektyw. Jedną z możliwych płaszczyzn rozważań jest spojrzenie na nie przez pryzmat kompetencji wykonywanych w tym obszarze przez Ministra Finansów. Pozawala ono nie tylko na przedstawienie instytucjonalnego i organizacyjnego punktu widzenia, ale także na wskazanie układu relacji pomiędzy podmiotami wykonującymi kompetencje w tym zakresie. Takie ujęcie więc ma tak walory teoretyczne, jak 
„Wolne środki” w ustawie o finansach publicznych...

praktyczne odniesienie. Wydaje się, że uzasadnione jest rozważenie w tym kontekście instytucji prawa finansów publicznych, jakimi są tzw. wolne środki.

Minister Finansów ustawowo został wskazany do przyjmowania wolnych środków w depozyt jako podmiot działający w imieniu Skarbu Państwa. Działalność ta służyć ma dwóm celom: po pierwsze sfinansowaniu potrzeb pożyczkowych budżetu państwa, po drugie zarządzaniu długiem Skarbu Państwa ${ }^{1}$. Powierzenie szczególnych kompetencji explicite Ministrowi Finansów nastąpiło dopiero na podstawie znowelizowanych przepisów ustawy o finansach publicznych w 2010 r. ${ }^{2}$. Na marginesie dodać wypada, że kwestia lokat wolnych środków była normatywnie określona także przed 2010 r. z tym, że Minister Finansów nie był upoważniony ustawowo do przyjmowania ich w depozyt ${ }^{3}$. Dodatkowo należy

1 Art. 78a ustawy z dnia 27 sierpnia 2009 o finansach publicznych (Dz.U. z 2017 r., poz. 2077 ze zm.), dalej: u.f.p.

2 Zob. art. 1 pkt 6 ustawy z 16 grudnia 2010 r. o zmianie ustawy o finansach publicznych oraz niektórych innych ustaw (Dz.U. Nr 257, poz. 1726.), dalej: nowelizacja u.f.p. z 2010 r. Zmiana weszła w życie 1 maja 2011 r.

3 W literaturze przedmiotu pierwowzoru depozytu doszukuje się tzw. lokatach budżetowych stosowanych w okresie PRL. Pisał o tym szeroko J. Głuchowski, Lokaty budżetowe w Polsce, Toruń 1968, tegoż, Lokaty budżetowe [w:] M. Weralski (red.), System instytucji prawno-finansowych PRL, t. II, Instytucje budżetowe, Wrocław-WarszawaKraków-Gdańsk-Łódź 1982, s. 377. Ustawa o finansach publicznych z 1998 r. co prawda powierzała Ministrowi Finansów zadania wynikające z zarządzania długiem Skarbu Państwa poprzez zarządzanie wolnymi środkami poprzez lokowanie ich na rynku finansowym, nie definiowała jednak pojęcia wolnych środków, a omawiane kompetencje Ministra ograniczała tylko do wolnych środków budżetu państwa zob. art. 41 ustawy z dnia 26 listopada 1998 r. o finansach publicznych (tekst. jedn. Dz.U. z 2003 r., Nr 15, poz. 148 ze zm. - dalej: u.f.p. z 1998). Ustawa o finansach publicznych z 2005 r. wprowadziła zasadę swobody lokowania wolnych środków przez niektóre jednostki sektora finansów publicznych w skarbowych papierach wartościowych, w obligacjach emitowanych przez jednostki samorządu terytorialnego lub na rachunkach bankowych w bankach mających siedzibę na terytorium Rzeczypospolitej Polskiej (art. 38 ustawy z dnia 30 czerwca 2005 r. o finansach publicznych, Dz.U. z 2005 r. Nr 249, poz. 2104 ze zm., dalej: u.f.p. z 2005). Co do zarządzania wolnymi środkami budżetu państwa, to niezmiennie leżało to w sferze uprawnień Ministra Finansów (art. 72 u.f.p. z 2005 r.). W pierwotnej wersji u.f.p. z 2009 r. zawarto jedynie uprawnienia przysługujące jednostkom sektora finansów publicznych do dokonywania lokat wolnych środków. Podmiotowo wyłączone z zakresu tej regulacji były jedynie organy władzy publicznej, jednostki budżetowe oraz samorządowe zakłady budżetowe. Przedmiotowo natomiast wyłączeniu podlegały środki z dotacji z budżetu. 
zauważyć, że uprawnienia Ministra Finansów w powyższym zakresie ulegają sukcesywnemu rozszerzaniu, o czym świadczą także nowelizacje ustawy o finansach publicznych z 2014 r. ${ }^{4}$ oraz $2018 \mathrm{r} .{ }^{5}$

Znamienne, że uprawnienia Ministra Finansów w podjętym obszarze badań obejmują kilka perspektyw rozważań. Z jednej strony są to uprawnienia tego organu do przyjmowania wolnych środków od jednostek sektora finansów publicznych w depozyt, a w konsekwencji wiążące się z tym obowiązki zarządzania nimi. Z drugiej strony są to kompetencje do lokowania wolnych środków budżetowych oraz zarządzania aktywami i pasywami finansowymi na rynku finansowym. Minister Finansów występuje w powyższych sytuacjach w odmiennych rolach. Wydaje się jednak, że ustawa o finansach publicznych nie dość precyzyjnie je definiuje i określa oba zakresy działania tego organu, pozostawiając pole do elastycznych czy wręcz dyskrecjonalnych działań.

\section{Normatywne ujęcie wolnych środków i zasad ich lokowania}

Uzasadnione jest rozpoczęcie przedmiotowych rozważań od poczynienia kilku uwag odnoszących się do normatywnego ujęcia wolnych środków. Obowiązująca ustawa o finansach publicznych definiuje wolne środki jednostki sektora finansów publicznych jako znajdujące się w jej dyspozycji środki, które nie są wydatkowane w określonym dniu na wykonywanie zadań oraz funkcjonowanie danej jednostki. Pojęcie to nie obejmuje środków w walutach obcych ${ }^{6}$, a także pochodzących z dotacji z budżetu ${ }^{7}$.

Dokonywanie lokat z wolnych środków mogło mieć trojaką postać: w skarbowych papierach wartościowych, w obligacjach emitowanych przez jednostki samorządu terytorialnego oraz na rachunkach bankowych w bankach mających siedzibę na terytorium $\mathrm{RP}$.

4 Ustawa z 26 września 2014 r. o zmianie ustawy o finansach publicznych oraz niektórych innych ustaw (Dz.U. z 2014 r., poz. 1626), dalej: nowelizacja u.f.p. z 2014 r.

5 Ustawa z dnia 3 lipca 2018 r. Przepisy wprowadzające ustawę - Prawo o szkolnictwie wyższym i nauce (Dz.U. z 2018 r., poz.1669) dalej: przepisy wprowadzające PSWiN z 2018 r.

$6 \quad$ Art. 48 ust 3 i 4 u.f.p.

7 Art. 48 ust 1, 2 u.f.p. 
Podkreśla się, iż celem omawianej instytucji prawnej jest zapewnienie efektywnego wykorzystania środków publicznych zgromadzonych na rachunkach jednostek sektora finansów publicznych. Realizacja tego celu opiera się na dwóch podstawowych zasadach. Po pierwsze, pozostające w dyspozycji jednostek sektora finansów publicznych środki, które w danym momencie nie są wykorzystywane na finansowanie wydatków jednostki, powinny zostać zagospodarowane w ten sposób, by przynieść dochody z ich posiadania. Po drugie, sposób gospodarowania tymi środkami powinien zapewniać bezpieczeństwo środków angażowanych w operacje służące uzyskaniu dodatkowych dochodów ${ }^{8}$. Zatem wydaje się uzasadnione nie tylko z praktycznego, ale także z naukowego punktu widzenia rozważenie sposobu realizacji nakreślonych celów. W ten aspekt natomiast wpisują się kompetencje Ministra Finansów.

Obowiązująca ustawa o finansach publicznych wprowadziła dwie formuły lokowania wolnych środków. Formuła pierwsza obejmuje zasadę swobody lokowania wolnych środków, stanowiącą uprawnienie określonych podmiotów do dokonywania lokat wolnych środków w czterech dopuszczalnych formach: w skarbowych papierach wartościowych, w obligacjach emitowanych przez jednostki samorządu terytorialnego, na rachunkach bankowych w bankach mających siedzibę na terytorium RP; co znamienne czwartą formą dodaną w nowelizacji z 2010 r. jest depozyt u Ministra Finansów. Druga formuła lokowania wolnych środków przybiera obowiązkową postać lokowania w formie depozytu u Ministra Finansów ${ }^{9}$.

Zasada swobody lokowania wolnych środków w formie depozytu aktualnie dotyczy jedynie: jednostek samorządu terytorialnego i ich związ-

8 W. Misiąg, Ustawa o finansach publicznych [w:] W. Misiąg (red.), Ustawa o finansach publicznych. Ustawa o odpowiedzialności za naruszenie dyscypliny finansów publicznych. Komentarz, Warszawa 2019, s. 185 i n.

$9 \quad$ Szerzej: W. Bożek, Depozyt u Ministra Finansów - stan obecny i przyszłe zmiany [w:] E. Kowalewska, P. Mańczyk (red.), Współczesne problemy bankowości i sektora finansów publicznych, tom I, Szczecin 2015, s. 265-279, tegoż: Komentarz do art. 78a-78g [w:] Z. Ofiarski (red.), Ustawa o finansach publicznych. Komentarz, Warszawa 2019, SIP LEX/El. 
ków ${ }^{10}$, ZUS i zarządzanych przez niego funduszy oraz KRUS i funduszy zarządzanych przez Prezesa KRUS oraz uczelni publicznych ${ }^{11}$. Nadto w odniesieniu do uczelni publicznych dopuszczono możliwość dokonywania lokat wolnych środków na rachunkach bankowych w bankach mających siedzibę na terytorium Rzeczypospolitej Polskiej jedynie na okres nie dłuższy niż 3 dni. Ograniczenie w zakresie terminu lokowania nie dotyczy jednak środków w walutach obcych ${ }^{12}$. Przed nowelizacją ustawy o finansach publicznych z 2014 r. katalog podmiotów dysponujących prawem swobodnego wyboru co do formy lokowania wolnych środków był znacznie szerszy ${ }^{13}$.

Swoboda lokowania wolnych środków nie ma pełnego wymiaru. Ustawodawca wprowadza pewne ograniczenia wobec dwóch grup podmiotów. Do pierwszej zakwalifikowane są samodzielne publiczne zakłady opieki zdrowotnej, dla których podmiotem tworzącym jest jednostka samorządu terytorialnego, samorządowe instytucje kultury oraz samorządowe osoby prawne z wyłączeniem wojewódzkich funduszy ochrony środowiska i gospodarki wodnej. Podmioty należące do tej grupy mogą dokonywać lokat wolnych środków, z wyjątkiem środków pochodzących $\mathrm{z}$ dotacji z budżetu, także $\mathrm{w}$ formie depozytu u jednostki samorządu terytorialnego $^{14}$.

Do drugiej grupy zaliczono uczelnie publiczne, które mogą dokonywać lokat wolnych środków na rachunkach bankowych w bankach mających siedzibę na terytorium Rzeczypospolitej Polskiej jedynie na okres

10 Szerzej: E. Rutkowska-Tomaszewska, Lokowanie wolnych środków przez jednostki samorzqdu terytorialnego w bankach, „Finanse Komunalne” 2012, nr 4, s. 25-32.

11 Art. 1 pkt 4 nowelizacji u.f.p. z 2014 r.

12 Zob. art. 48 ust. 1 b u.f.p.

13 W latach 2010-2014 oprócz wyżej wskazanych jednostek samorządu terytorialnego oraz ich związków, ZUS i zarządzanych przez niego funduszy oraz KRUS i funduszy zarządzanych przez Prezesa KRUS oraz uczelni publicznych prawo do swobody lokowania wolnych środków miały także instytucje gospodarki budżetowej, samodzielne publiczne zakłady opieki zdrowotnej, PAN i tworzone przez nią jednostki organizacyjne, państwowe i samorządowe instytucje kultury oraz państwowe instytucje filmowe, samorządowe osoby prawne utworzone na podstawie odrębnych ustaw w celu wykonywania zadań publicznych, z wyłączeniem przedsiębiorstw, instytutów badawczych, banków i spółek prawa handlowego.

Art. 48 ust 1a u.f.p. 
nie dłuższy niż 3 dni. Ograniczenie to jednak w zakresie terminu lokowania nie dotyczy środków w walutach obcych ${ }^{15}$.

Warto podkreślić, biorąc powyższe pod uwagę, że ustawowo został określony szeroki krąg podmiotów mających obowiązek stosować formułę obligatoryjnego lokowania wolnych środków w formie depozytu u Ministra Finansów ${ }^{16}$. Zaliczyć do nich należy: agencje wykonawcze, instytucje gospodarki budżetowej, NFZ, PAN i jednostki przez nią tworzone oraz samodzielne publiczne zakłady opieki zdrowotnej, dla których podmiotem tworzącym jest minister, centralny organ administracji rządowej, wojewoda lub uczelnia medyczna, państwowe instytucje kultury, państwowe osoby prawne, a także wojewódzkie fundusze ochrony środowiska i gospodarki wodnej ${ }^{17}$. Taki stan prawny pozwala na stwierdzenie o rozszerzeniu uprawnień Ministra Finansów, co przejawia z jednej strony w zwiększeniu zakresu oddziaływania na gospodarkę finansową tych jednostek, a z drugiej zwiększeniu zakresu działań pozwalających Ministrowi oddziaływać w obszarze długu publicznego w szczególności długu Skarbu Państwa ${ }^{18}$.

Ratio legis wprowadzenia obowiązku lokowania wolnych środków wybranych jednostek sektora finansów publicznych w formie depozytu prowadzonego przez Ministra Finansów związane jest z celami wynikającymi ze Strategii zarzq̨dzania długiem, czyli obniżeniem poziomu długu publicznego oraz kosztów jego obsługi m.in. poprzez zmniejszenie po-

15 Art. 48 ust 1b u.f.p. (dodany art. 120 przepisów wprowadzających PSWiN z 2018).

16 Na marginesie dodać wypada, że nowelizacją u.f.p. z 2014 r. został wprowadzony podobny instrument zarządzania płynnością dla jednostek samorządu terytorialnego. Art. 48 ust 1a u.f.p.

17 Należy także zwrócić uwagę, że art. 2 i art. 3 nowelizacji u.f.p. z 2014 r. przewidują zmiany odpowiednio w ustawie z dnia 17 listopada 1964 r. - Kodeks postępowania cywilnego (Dz.U. z 2018 r., poz.1360 ze zm.) oraz ustawie z dnia 27 lipca 2001 r. Prawo o ustroju sądów powszechnych (Dz.U. z 2019 r., poz. 52 ze zm.). Sądy jako państwowe jednostki budżetowe uprawnione są do przyjmowania depozytów, np. tytułem zabezpieczenia, spłaty zobowiązania czy poręczenia majątkowego. W stanie prawnym przed nowelizacją depozyty w postaci środków pieniężnych przechowywane były w sądzie lub utrzymywane w banku na rachunku sądu. Aktualnie depozyty sądowe muszą być wpłacane i utrzymywane na oprocentowanym rachunku depozytowym Ministra Finansów. Ob. art. 78a u.f.p. 
trzeb pożyczkowych Skarbu Państwa, wynikające z wykorzystania aktywów finansowych jednostek sektora finansów publicznych w zarządzaniu płynnością budżetu państwa. Dotychczasowe doświadczenia potwierdzały, że znaczna część środków jednostek sektora finansów publicznych nie jest wykorzystywana na bieżącą działalność jednostek i lokowana jest przede wszystkim w sektorze bankowym. Natomiast Minister Finansów, działając w imieniu Skarbu Państwa, zobligowany był w celu finansowania potrzeb pożyczkowych budżetu państwa do pozyskiwania na rynku środków poprzez sprzedaż skarbowych papierów wartościowych. Znaczna część tych środków pochodziła z sektora bankowego, w tym ze środków lokowanych przez jednostki sektora finansów publicznych w bankach. Taka sytuacja powodowała swego rodzaju nieefektywność z punktu widzenia zarządzania płynnością Skarbu Państwa i całego sektora finansów publicznych poprzez powstanie dodatkowych kosztów w postaci różnicy pomiędzy kosztem zaciąganych przez Skarb Państwa zobowiązań a oprocentowaniem krótkoterminowych lokat jednostek sektora finansów publicznych w bankach. Powierzenie zarządzania płynnością i potrzebami pożyczkowymi jednostek sektora finansów publicznych instytucji odpowiedzialnej za zarządzanie długiem publicznym funkcjonuje w różnym zakresie i formie w niektórych państwach OECD, w tym m.in. w Finlandii i Irlandii ${ }^{19}$. Wprowadzenie do porządku prawnego instrumentu polegający na wykorzystywaniu aktywów finansowych jednostek sektora finansów publicznych pozwoliło zatem na zmniejszenie uzależnienia sektora publicznego od zdobywania środków na rynku i jest jednym z głównych sposobów obniżania kosztów i ryzyka budżetowego prowadzących do obniżenia poziomu pożyczkowych potrzeb budżetu państwa ${ }^{20}$. Sumując, wyposażenie Ministra Finansów w omawiane instrumenty umożliwia mu bardziej skuteczne zarządzanie długiem Skarbu Państwa. Zarówno cel, jak i prawnie dopuszczalne możliwości rozporządzania oddanymi w depozyt

19 Zob. uzasadnienie do rządowego projektu ustawy o zmianie ustawy o finansach publicznych oraz niektórych innych ustaw (Druk sejmowy nr 3576, Sejm VI kadencji), por. uzasadnienie do rządowego projektu ustawy o zmianie ustawy o finansach publicznych oraz niektórych innych ustaw (druk sejmowy nr 2509, Sejm VII kadencji).

20 Zob. K. Marchewka-Bartkowiak, Skonsolidowany system zarzq̨dzania płynnościq sektora publicznego, „Analizy Sejmowe BAS” 2010, nr 19, s. 6. 
pieniędzmi świadczą, że konstrukcja ta nawiązuje do instytucji depozytu nieprawidłowego ${ }^{21}$. Jednocześnie instrument ten poszerza dyskrecjonalną władzę Ministra Finansów oddziaływującą na gospodarkę finansową jednostek sektora de facto niepodlegających Ministrowi Finansów.

Normatywna odrębność dotyczy wolnych środków państwowych funduszy celowych ${ }^{22}$. W tym przypadku Minister Finansów został upoważniony do przyjmowania w zarządzanie tych środków, a nie w depozyt. Po stronie dysponentów państwowych funduszy celowych istnieje w związku z tym obowiązek przekazywania wolnych środków, z wyjątkiem środków pochodzących $\mathrm{z}$ dotacji. $\mathrm{W}$ doktrynie zawraca się uwagę, że mimo tego, iż ustawa o finansach publicznych wyraźnie odróżnia wolne środki przyjęte w depozyt od wolnych środków przyjętych w zarządzanie, to $\mathrm{w}$ sensie formalnoprawnym podlegają one analogicznym regułom. Rodzi się w związku z tym uzasadnione pytanie o możliwości żądania przez Ministra Finansów realizacji przez dysponentów funduszy wynikających z ustawy obowiązków. Ustawa nie przewiduje bowiem sankcji związanych z nieprzekazaniem wolnych środków w zarządzanie. Nie jest też do końca jasne, czy ustawowo wprowadzona różnica pomiędzy depozytem a zarządzaniem wolnymi środkami dotyczy większej autonomii Ministra Finansów w wykorzystaniu tych funduszy ${ }^{23}$.

\section{Formalnoprawne ramy przyjmowania środków w depozyt lub zarządzanie przez Ministra Finansów}

Uprawniona jest konstatacja, że ustawa o finansach publicznych paralelnie do obowiązków poszczególnych jednostek zaliczonych do sektora finansów publicznych upoważnia Ministra Finansów, aby w imieniu Skarbu Państwa przyjmował wolne środki w depozyt lub zarządzanie.

21 Art. 845 ustawy z dnia 23 kwietnia 1964 r. Kodeks cywilny (tekst jedn. Dz.U. z 2018 r., poz.1025 ze zm.).

22 Art. 78 d u.f.p.

23 Zob. P. Pomorski [w:] P. Smoleń (red.), Ustawa o finansach publicznych. Komentarz, Warszawa 2014, s. 508. 
Z formalnoprawnego punktu widzenia sposób działania Ministra Finansów jest zróżnicowany w zależności od ścieżki prawnej dotyczącej wolnych środków. Trzeba tu wyróżnić dwie sytuacje.

Po pierwsze, jeśli lokowanie wolnych środków w formie depozytu następuje na zasadzie swobody wyboru - Minister Finansów zawiera z odpowiednią jednostką sektora finansów publicznych umowę. Ponadto przejęcie wolnych środków w depozyt na okres do 3 dni uwarunkowane bankową obsługą danej jednostki przez Bank Gospodarstwa Krajowego.

Ustawowe regulacje nie precyzują, jaka winna być treść umowy ${ }^{24}$. Wydaje się, że skoro jednostki mogą wybrać depozyt u Ministra Finansów jako jedną z czterech dopuszczalnych form, to treść umowy powinna być przedmiotem negocjacji między jej stronami. Można więc twierdzić, że Minister Finansów, występując w tym wypadku w imieniu Skarbu Państwa na płaszczyźnie prywatnoprawnej (dominium, a nie imperium), ma możliwość kształtowania jej treści. Jednocześnie warto odnotować, że ustawa o finansach publicznych wskazuje sposób ustalania wysokości odsetek od wolnych środków przyjętych w depozyt ${ }^{25}$, czyli kluczowego elementu tej umowy, o czym będzie mowa niżej. Rodzi się więc pytanie, czy Minister Finansów może kształtować umowę tak, aby stymulować jednostki sektora do wyboru właśnie tej formy lokowania wolnych środków? Dodatkowo należy zwrócić uwagę na ostatnie zmiany ustawowe ${ }^{26}$. Minister Finansów zyskał dodatkowe uprawnienie do przyjmowania wolnych środków w depozyt na warunkach określonych w umowie od podmiotów niebędących jednostkami sektora finansów publicznych, a zaliczanych do sektora instytucji rządowych i samorządowych w rozumieniu przepisów $\mathrm{UE}^{27}$. Regulacja ta rozbudowuje zakres podmiotowy ${ }^{28}$, jedno-

\footnotetext{
Nie znajdują tu zastosowania przepisy rozporządzenia wykonawczego Ministra Finansów. Art. 78e u.f.p.

Zob. art. 7 ustawy z dnia 17 stycznia 2019 r. o zmianie ustawy o Bankowym Funduszu Gwarancyjnym, systemie gwarantowania depozytów oraz przymusowej restrukturyzacji oraz niektórych innych ustaw (Dz.U. z 2019 r. poz. 326).

27 Zob. Rozporządzenie Parlamentu Europejskiego i Rady (UE) nr 549/2013 z dnia 21 maja 2013 r. w sprawie europejskiego systemu rachunków narodowych i regionalnych w Unii Europejskiej (Dz.Urz. UE L 174 z 26.06.2013, s. 1, ze zm.).

28 Jak wynika z uzasadnienia zmian omawianych przepisów, zakresem podmiotowym objęte byłyby takie podmioty wchodzące do sektora instytucji rządowych i samorzą-
} 
cześnie poszerzając możliwości oddziaływania Ministra na dług publiczny ${ }^{29}$. Dodać wypada, że powołane przepisy stanowią podstawę prawną do rozszerzania uprawnień do oddziaływania Ministra poza sektor finansów publicznych.

Po drugie, inaczej kształtuje się pozycja Ministra Finansów w odniesieniu do wolnych środków jednostek sektora finansów publicznych obowiązkowo lokowanych $\mathrm{w}$ formie depozytu, a także względem wolnych środków państwowych funduszy celowych przekazywanych w zarządzanie. Szczegółowe warunki przekazywania i przyjmowania wolnych środków wskazanych kategorii jednostek sektora finansów publicznych określone zostały przez Ministra Finansów na podstawie delegacji ustawowej w odrębnym rozporządzeniu ${ }^{30}$. Minister Finansów występuje zatem w tym przypadku jako organ stanowiący prawo. Jego działanie ma charakter jednostronnego ustalenia zasad, czyli działa w imieniu Skarbu Państwa w ramach imperium. Ze wskazanego aktu normatywnego wynikają terminy przekazywania środków i terminy ich zwrotu, a także wysokość lub sposób obliczania oprocentowania środków przyjętych w depozyt lub zarządzanie; szczegółowe warunki rozwiązywania depozytów lub zwrotu środków przekazanych w zarządzanie przed terminem, na jaki został utworzony depozyt lub środki zostały przekazane w zarządzanie; sposób

dowych jak Fundusz oraz fundusze utworzone ustawowo w Banku Gospodarstwa Krajowego, z których środki służą finansowaniu zadań publicznych (np. Krajowy Fundusz Drogowy). Znamienne, że według ustawy o finansach publicznych wskazane wyżej jednostki nie są zaliczane do sektora finansów publicznych. Zob. szerzej uzasadnienie do ustawy z dnia 17 stycznia 2019 r. o zmianie ustawy o Bankowym Funduszu Gwarancyjnym, systemie gwarantowania depozytów oraz przymusowej restrukturyzacji oraz niektórych innych ustaw (druk sejmowy nr 2877, Sejm VII kadencji).

29 W uzasadnieniu do ustawy wprost wskazuje się, że środki ulokowane w ramach konsolidacji zarządzania płynnością na rachunkach Ministra Finansów przez BFG, fundusze BGK oraz przedsiębiorstwa publiczne zaliczone do sektora instytucji rządowych i samorządowych potencjalnie mogłyby przyczynić się do zmniejszenia potrzeb pożyczkowych o wartość ulokowanych środków, a tym samym obniżenia długu sektora instytucji rządowych i samorządowych zgodnie z definicją UE, stanowiąc zwiększenie bezpieczeństwa potrzeb pożyczkowych budżetu państwa.

30 Rozporządzenie Ministra Finansów z dnia 11 grudnia 2014 r. w sprawie wolnych środków niektórych jednostek sektora finansów publicznych przyjmowanych przez Ministra Finansów w depozyt lub zarządzanie (Dz.U. z 2014 r., poz. 1864) dalej: rozporządzenie MF w sprawie wolnych środków niektórych JSFP. 
składania i wzory dyspozycji przekazania środków w depozyt lub zarządzanie Ministrowi Finansów i ich zwrotu oraz dyspozycji rozwiązania depozytu lub zwrotu środków przekazanych w zarządzanie przed terminem, na jaki został utworzony depozyt lub środki zostały przekazane w zarządzanie. Ustawa o finansach publicznych wymaga, aby Minister Finansów, wydając rozporządzenie, kierował się potrzebą zapewnienia bezpieczeństwa środków publicznych i terminowej realizacji zadań finansowanych z tych środków przez jednostki sektora finansów publicznych oraz zwiększenia efektywności zarządzania środkami publicznymi i dbałością o finanse publiczne, a w zakresie wysokości oprocentowania również terminami, na jakie środki są przekazywane w depozyt lub zarządzanie, natomiast w zakresie składania dyspozycji także potrzebą ujednolicenia składanych dokumentów oraz możliwościami wykorzystania systemów teleinformatycznych ${ }^{31}$.

Wolne środki przyjęte w depozyt lub zarządzanie Ministra Finansów podlegają oprocentowaniu. Jego wysokość została ustalona normatywnie w zależności od okresu, na jaki zostały przyjęte w depozyt lub zarządza$n^{3}{ }^{32}$. Jednocześnie w pewnym zakresie Minister Finansów uzyskał możliwość wpływania na wysokość tego oprocentowania poprzez prawo do kształtowania mnożnika wpływającego na wysokość stopy oprocentowania. Przyznanie tego uprawnienia wiąże się z koniecznością elastycznego reagowania na sytuację na rynku finansowym. Wysokość tego mnożnika jest ustalana przez Ministra Finansów i ogłaszana w formie komunikatu na stronach internetowych Ministerstwa Finansów. Można uznać, że jest to kolejny przejaw realizacji zasady jawności, będący jednocześnie formą oddziaływania na gospodarkę finansową jednostek sektora finansów publicznych.

Obsługę operacji - wszelkich czynności prawnych i faktycznych związanych z przyjmowaniem wolnych środków w zarządzanie lub depozyt i ich zwrotem - Minister Finansów może powierzyć Bankowi Gospodarstwa Krajowego (BGK). Konieczne w tym względzie jest zawarcie umowy o charakterze odpłatnym. Użycie terminu „może” świadczyłoby

\footnotetext{
Art. 78 g ust. 2 u.f.p.

Ob. art. 78e u.f.p. oraz § 7 rozporządzenia MF w sprawie wolnych środków niektórych JSFP.
} 
o możliwości działania Ministra Finansów w sferze uznania. Nie można jednak do końca popierać tej tezy, z uwagi na to, że nie wskazano jednocześnie innego podmiotu poza BGK, który taką obsługę mógłby wykonywać. Trudno też przyznać, że Minister ma swobodę w omawianym zakresie, gdyż wydaje się, że czynności tego rodzaju nie mogłyby być wykonane przez urząd go obsługujący ${ }^{33}$. Trzeba odnotować, że nowe rozwiązania prawne w zakresie przyjmowania depozytów sądowych zobowiązały Ministra Finansów do otwierania w BGK rachunków depozytowych w złotych lub walutach obcych, na których przechowywane będą te depozyty ${ }^{34}$.

Pozytywna ocena rozwiązań prawnych związanych z przyjmowaniem przez Ministra Finansów wolnych środków w depozyt lub zarządzanie oparta jest przede wszystkim na argumencie dotyczącym zarządzania środkami publicznymi oraz zarządzania długiem. Zogniskowanie wyżej omówionych działań w ręku Ministra Finansów jest w pełni uzasadnione, z uwagi na jego kompetencje związane z finansowaniem pożyczkowych potrzeb budżetu państwa. Nie można jednak nie dostrzegać, że poprzez omówione instrumenty zasięg oddziaływania Ministra Finansów uległ znacznemu poszerzeniu, gdyż dotyczy jednostek niepowiązanych z budżetem lub powiązanych budżetowaniem netto, nadto wykracza także poza zdefiniowany w ustawie o finansach publicznych - sektor finansów publicznych. Co prawda nie można mówić tu o dyskrecjonalności działania samego Ministra, z uwagi na ustawowy poziom regulacji obligujący do lokowania wolnych środków w formie depozytu lub przekazania w zarządzanie. Niemniej taki stan prawny tworzy swoiste relacje między jednostkami sektora spoza sfery budżetowej z ministrem do spraw budżetu, w niektórych wypadkach wyłączające swobodę lokowania wolnych środków. Jak wskazywano, sukcesywne rozszerzanie kompetencji Ministra Finansów i odpowiadających im obowiązków niektórych jednostek sekto-

33 Wydaje się, że art. $78 f$ u.f.p. został w związku z powyższym wadliwie skonstruowany.

34 Jak wynika z uzasadnienia ustawy nowelizującej ustawę o finansach publicznych, wybór BGK wynika z faktu, iż w związku z konsolidacją środków publicznych zostały już stworzone odpowiednie mechanizmy w ramach BGK pozwalające na wykorzystanie w zarządzaniu płynnością budżetu państwa środków przyjętych przez Ministra Finansów w depozyt lub zarządzanie. Przy zastosowaniu tych mechanizmów Minister Finansów uzyskał prawo do wykorzystywania środków stanowiących depozyty sądowe. 
ra finansów publicznych rzutuje na sposób prowadzenia przez te ostatnie gospodarki finansowej. Wiąże się to nie tylko z kwestią dochodów w postaci odsetek od depozytów, ale także np. z obowiązkiem otwierania rachunków bankowych w BGK ${ }^{35}$. Znamienne przy tym jest to, że środki przyjęte w depozyt i zarządzanie stanowią z punktu widzenia Ministra bardzo użyteczny instrument w zarządzaniu płynnością długu Skarbu Państwa. Świadczy o tym waga, jaką Minister Finansów przykładał do zmian wprowadzonych w 2010 r., i rzeczywiste skutki na płaszczyźnie zarządzania długiem Skarbu Państwa ${ }^{36}$.

\section{Zakres zarządzania wolnymi środkami przez Ministra Finansów}

Podjęte w niniejszym opracowaniu rozważania wymagają także odniesienia się do zadań nałożonych ustawowo na Ministra Finansów wynikających z zarządzania długiem Skarbu Państwa. Wypełniane są one poprzez zarządzanie wolnymi środkami budżetu państwa oraz zarządzanie pasy-

\section{Zob. art. 196 ust 5 u.f.p.}

36 W Strategii Zarządzania Długiem Sektora Finansów Publicznych na lata 2013-2016 uznano, że jedną z najważniejszych zmian legislacyjnych, która miała bezpośredni wpływ na zarządzanie długiem publicznym, było wprowadzenie omawianego obowiązku lokowania wolnych środków na rachunku Ministra Finansów, a przez to wzmocnienie systemu zarządzania płynnością budżetu państwa. W wyniku tych zmian zmniejszyły się pożyczkowe potrzeby budżetu, a przez to nastąpiło obniżenie poziomu państwowego długu publicznego i kosztów obsługi długu Skarbu Państwa przy zachowaniu samodzielności jednostek w dysponowaniu środkami potrzebnymi na realizację ich zadań. W Strategiach jednoznacznie wykazywano, że nastąpiło zmniejszenie potrzeb pożyczkowych o wykorzystane wolne środki jednostek sektora finansów publicznych, a także nastąpiła minimalizacja kosztów obsługi długu w długim horyzoncie czasowym m.in z uwagi na wykorzystywanie wolnych środków jednostek sektora finansów publicznych w zarządzaniu płynnością budżetu państwa, w tym rozszerzenie grupy jednostek oraz zakresu wolnych środków objętych konsolidacją. Poziom wolnych środków kształtował się następująco: na koniec roku 2011 - 22,8 mld zł, na koniec roku 2012 - 28,3 mld zł.; na koniec roku 2013 - 29,7 mld zł, na koniec roku 2014 - 28,2 mld zł, na koniec 2015 - 36,7 mld zł, na koniec 2016 - 39,8 mld zł., na koniec 2017 - 42,2 mld zł, na koniec czerwca 2018 r. - 48,1 mld zł, zob. Strategie Zarządzania Długiem Sektora Finansów Publicznych: https://finanse-arch.mf.gov.pl/web/wp/dlugpubliczny/publikacje/strategie-zarzadzania-dlugiem (dostęp 24.04.2019 r.). 
wami finansowymi i aktywami finansowymi Skarbu Państwa ${ }^{37}$. Ustawa o finansach publicznych nie definiuje wskazanych pojęć, ograniczając się jedynie do przykładowego wskazania operacji, jakie w tym zakresie mogą być dokonywane, co daje Ministrowi Finansów szerokie pole do działań niewskazanych explicite w ustawie.

Zarządzanie wolnymi środkami budżetu obejmuje w szczególności ich lokowanie na rynku finansowym. Natomiast zarządzanie pasywami finansowymi i aktywami finansowymi obejmuje w szczególności wykonywanie operacji i działań na rynkach finansowych, które wpływają na zmianę struktury zadłużenia Skarbu Państwa, w celu: zwiększenia bezpieczeństwa finansowego potrzeb pożyczkowych budżetu państwa, obniżenia ryzyka lub kosztów obsługi długu Skarbu Państwa, realizacji innych zadań związanych z zarządzaniem długiem Skarbu Państwa określonych Strategii zarządzania długiem ${ }^{38}$.

Brak ustawowej definicji wolnych środków budżetu państwa sprawił, że w doktrynie podejmowane były próby odkodowania tego pojęcia. Według jednych rozumieć ten termin należy jako środki znajdujące się na rachunku bankowym jednostki sektora finansów publicznych, okresowo „niepotrzebne” do dokonania wydatków lub rozchodów ${ }^{39}$. Jednakże założenie to jest o tyle błędne, że nie chodzi tu o środki na rachunku bankowym jednostek sektora finansów publicznych, skoro w ustawie wyraźnie jest mowa o wolnych środkach budżetowych ${ }^{40}$. Inni autorzy wskazują, że wolne środki to takie, które okresowo nie są angażowane do realizacji wydatków lub rozchodów ${ }^{41}$. Mają one np. postać przejściowych nadwyżek na centralnym rachunku bieżącym budżetu państwa ${ }^{42}$. Problemy interpretacyjne co do ustalenia znaczenia terminu „wolnych środków” mają swoje źródło w niepoprawnie stosowanej terminologii w samej ustawie

\footnotetext{
Art. 78 ust. 1 pkt 2 u.f.p.

Art. 78 ust. 2 i 3 u.f.p.

Zob. L. Lipiec-Warzecha, Ustawa o finansach...

Art. 48 ust. 3 u.f.p. oraz art. 78 ust. 1 pkt 2 u.f.p.

1 Zob. Z. Ofiarski, [w:] M. Karlikowska, W. Miemiec, Z. Ofiarski, K. Sawicka, Ustawa o finansach publicznych. Komentarz, Wrocław 2010, s. 226.

42 C. Kosikowski, Nowa ustawa o finansach publicznych. Komentarz, Warszawa 2010, s. 233, P. Pomorski [w:] Ustawa o finansach..., s. 539.
} 
o finansach publicznych, która posługuje się dwoma pojęciami wolnych środków: po pierwsze tych, które pozostają w dyspozycji jednostek sektora finansów publicznych i mogą lub muszą być przez te jednostki lokowane m.in. w formie depozytu u Ministra Finansów; po drugie wolne środki budżetu państwa, co do których uprawnienie do zarządzania przyznano Ministrowi Finansów. W tym miejscu punktem odniesienia jest drugie z wymienionych ujęć. Można twierdzić, że niedookreślenie pojęcia wolnych środków ma swoje przełożenie na zakres kompetencji Ministra Finansów. Zwłaszcza gdy aktualna ustawa o finansach publicznych wskazuje, że zarządzanie tymi wolnymi środkami w szczególności obejmuje ich lokowanie na rynku finansowym. Interesujące jest to, że wprost w odniesieniu do wolnych środków budżetowych podano jedną z możliwości, przy czym nie jest to wskazanie enumeratywne, o czym świadczy użyte sformułowanie „w szczególności”. Ponadto zwrot „lokowanie na rynku finansowym” jest niezwykle pojemny. Samo pojęcie rynku finansowego, wobec braku definicji legalnej, nie zostało jednoznacznie zdefiniowane i przyjęte w doktrynie prawa. Od strony przedmiotowej ujmuje się rynek finansowy jako ogół działań o charakterze ekonomicznym i związanych z nimi czynności prawnych dokonywanych przy użyciu instrumentów finansowych i za pośrednictwem wyspecjalizowanych instytucji rynku finansowego, których przedmiotem jest przepływ i alokacja środków finansowych ${ }^{43}$. Od strony podmiotowej rynek finansowy klasyfikuje się z punktu widzenia instytucji finansowych, które świadczą usługi finansowe, czyli instytucji kredytowych, ubezpieczeniowych, inwestycyjnych ${ }^{44}$. Takie ujęcie jest paralelne z przepisami ustawy o nadzorze nad rynkiem

43 Zob. P. Zapadka, Aspekty prawne funkcjonowania rynku finansowego w Polsce, „Bank i Kredyt” 2002, nr 1, s. 28 i n. A. Jurkowska-Zeidler, Rynek finansowy, [w:] A. Drwiłło, D. Maśniak (red.), Leksykon prawa finansowego. 100 podstawowych pojęć, Warszawa 2009, s. 385; E. Wymeersch, The future of financial regulation and supervision in Europe. „Common Market Law Review” 2005., nr 4, s. 987-1010.

44 Zob. A. Jurkowska-Zeidler, Publicznoprawne formy oddziaływania państwa i Unii Europejskiej na instytucje kredytowe i finansowe [w:] J. Głuchowski (red.), System Prawa Finansowego. Prawo walutowe. Prawo dewizowe. Prawo rynku finansowego, t. IV, Warszawa 2010, s. 252. 
finansowym ${ }^{45}$. Biorąc pod uwagę jedynie sygnalnie wskazane bardzo treściowo pojemny termin rynku finansowego, należy uznać, że wyboru kategorii rynku oraz doboru instrumentów finansowych dokonuje Minister Finansów w oparciu o pozostawioną mu znaczną swobodę. Warto także odnotować, iż ta elastyczność działań Ministra nie jest w zasadzie ukierunkowana poza wskazaniem, że służy realizacji zadań wynikających z zarządzania długiem Skarbu Państwa.

Poza lokowaniem wolnych środków budżetu państwa na rynku finansowym Minister Finansów może także dokonywać lokat w złotych i walutach obcych oraz przeprowadzać inne operacje finansowe w Narodowym Banku Polskim lub innym banku ${ }^{46}$. Sumując, można zatem twierdzić, że zarówno dookreślenie w praktyce pojęcia „wolne środki budżetu” pozostawiono ministrowi do spraw budżetu, podobnie jak dobór instrumentów służących zarządzaniu tak w ujęciu przedmiotowym, jak podmiotowym.

Przypomnieć trzeba, że w dwóch już nieobowiązujących ustawach o finansach publicznych omawiane kompetencje Ministra Finansów był bardziej doprecyzowane przedmiotowo. Wyraźnie przyznawano upoważnienie Ministrowi Finansów co do możliwości dokonywania oprocentowanych lokat w odniesieniu do nadwyżek środków na centralnym rachunku bieżącym budżetu państwa. Zmianom ulegała jedynie kwestia wyboru banku, w jakim owe lokaty były dokonywane. Na gruncie ustawy z 1998 r. zasadniczo lokaty przejściowych nadwyżek dokonywane były w Narodowym Banku Polskim. Jednakże Ministrowi Finansów pozostawiono możliwość wyboru dowolnie wybranego banku, po zasięgnięciu decyzji prezesa $\mathrm{NBP}^{47}$. W ustawie z 2005 r. wyraźnie dokonano ograniczenia możliwości dokonywania przez Ministra Finansów oprocentowanych lokat z tzw. przejściowych nadwyżek do Narodowego Banku Polskiego lub Banku Gospodarstwa Krajowego ${ }^{48}$. W aktualnej ustawie, jak wyżej wskazano, brak analogicznych przepisów wskazujących explicite na możliwo-

45 Zob. art. 1 ustawy z dnia 21 lipca 2006 r. o nadzorze nad rynkiem finansowym (tekst jedn. Dz.U. z 2019 r. poz. 298, ze zm.).

46 Zob. art. 83 u.f.p.

47 Zob. art. 108 u.f.p. z 1998 r.

48 W doktrynie podkreślano, że to ograniczenie wprowadzono w toku prac legislacyjnych w Sejmie, co można odczytywać jako celowe ograniczenie swobody Ministra Finansów. 
ści lokowania przejściowych nadwyżek. Niemniej skoro nie został doprecyzowany zakres pojęcia wolne środki, to idąc za głosem doktryny, wydaje się, że do tego pojęcia można zaliczyć też nadwyżki przejściowe. Nadto skoro w ustawie jest mowa o uniwersalnym uprawnieniu Ministra Finansów do dokonywania lokat w złotych i walutach obcych oraz prowadzeniu operacji finansowych w NBP lub innym banku, to można twierdzić, że dotyczy to także tej kategorii środków. Sumując, można stwierdzić, że w porównaniu do ustaw z 1998 i 2005 r. obowiązująca ustawa z 2009 r. znaczenie rozszerza kompetencje Ministra Finansów, zarówno co do instrumentów, jak i co do wyboru banku, w którym operacje finansowe w tym lokaty mogą być prowadzone. Wydaje się, że działania te Minister prowadzi w oparciu o stosunkowo dużą swobodę przyznaną mu ustawowo.

W ramach zarządzania długiem Skarbu Państwa Minister Finansów uprawniony jest do zarządzania pasywami finansowymi i aktywami finansowymi. Działania te obejmują w szczególności wykonywanie operacji i działań na rynkach finansowych ${ }^{49}$, które wpływają na zmianę struktury zadłużenia Skarbu Państwa. Na początku należy poczynić dwie uwagi. Po pierwsze, w przeciwieństwie do regulacji w zakresie wolnych środków budżetowych w omawianym wypadku wskazane zostały cele, jakie mają przyświecać Ministrowi Finansów: 1) zwiększenia bezpieczeństwa finansowego potrzeb pożyczkowych budżetu państwa; 2) obniżenia ryzyka lub kosztów obsługi długu Skarbu Państwa; 3) realizacji innych zadań związanych z zarządzaniem długiem Skarbu Państwa, określonych w Strategii zarządzania długiem ${ }^{50}$. Po drugie, podobnie jak w przypadku wolnych środków budżetu państwa, w ustawie zostały użyte pojęcia, które nie zostały zdefiniowane, są nimi pasywa i aktywa finansowe. Należy ocenić takie rozwiązanie legislacyjne negatywnie $\mathrm{z}$ uwagi na trudności w jednoznacznej transpozycji pojęć ekonomicznych na grunt prawa. Zarówno bowiem próby interpretacji tych pojęć w oparciu o ustawę o rachunkowo-

\footnotetext{
49 Szerzej: E. Kowalewska, Komentarz do art. 78 [w:] Z. Ofiarski (red.), Ustawa o finansach publicznych. Komentarz, Warszawa 2019, SIP LEX/el.

50 Zob. art. 78 ust. 3 u.f.p.
} 
ści ${ }^{51}$, jak i posiłkowanie się prawem Unii Europejskiej w tym zakresie nie rozwiewają wątpliwości interpretacyjnych ${ }^{52}$. W doktrynie ekonomicznej pojęcia te używane są w kontekście bilansowego podejścia w zarządzaniu długiem, której zasady polegają na koordynacji zarządzania portfelem i ryzykiem szeroko zdefiniowanych i aktywów (w tym należności finansowych, akcji i udziałów kapitałowych), i pasywów finansowych (w tym długu konwencjonalnego i potencjalnego ${ }^{53}$. Kwestia niedookreśloności obu wskazanych wyżej pojęć, rodzi zasadnicze wątpliwości natury insty-

51 W doktrynie podejmowane są próby odkodowania znaczenia tych pojęć przy zastosowaniu wykładni systemowej, zob. Z. Ofiarski, [w:] M. Karlikowska, W. Miemiec, Z. Ofiarski, K. Sawicka, Ustawa o finansach publicznych..., s. 225. Zgodnie z art. 3 ust. 1 pkt 24 ustawy z dnia 29 września 1994 r. o rachunkowości (tekst jedn. Dz.U. z 2019 r. poz. 351 ze zm.) przez aktywa finansowe rozumie się aktywa pieniężne, instrumenty kapitałowe wyemitowane przez inne jednostki, a także wynikające z kontraktu prawo do otrzymania aktywów pieniężnych lub prawo do wymiany instrumentów finansowych z inną jednostką na korzystnych warunkach. Natomiast jeśli chodzi o pasywa finansowe, choć w ustawie o rachunkowości wielokrotnie termin „pasywa” został użyty, nie jest on zdefiniowany.

52 W rozporządzeniu Parlamentu Europejskiego i Rady (UE) nr 549/2013 z dnia 21 maja 2013 r. w sprawie europejskiego systemu rachunków narodowych i regionalnych w Unii Europejskiej pojęcie aktywów finansowych pojawia się wielokrotnie, przy czym przyjęto tu definicję bardzo szeroką. W skład aktywów finansowych wchodzą wszelkie należności finansowe, udziały kapitałowe oraz złoto kruszcowe jako składnik złota monetarnego. Aktywa finansowe są środkami tezauryzacji reprezentującymi korzyść lub serie korzyści przysługujące ich właścicielowi ekonomicznemu z tytułu posiadania tych aktywów lub korzystania z nich w określonym czasie. Stanowią one sposób na przenoszenie wartości z jednego okresu sprawozdawczego do drugiego. Korzyści są realizowane przez płatności, z reguły gotówkę (AF.21) i depozyty bieżące rozliczeniowe (AF.22). Zob. Rozdział 5 rozporządzenia Parlamentu Europejskiego i Rady (UE) nr 549/2013 z dnia 21 maja 2013 r. w sprawie europejskiego systemu rachunków narodowych i regionalnych w Unii Europejskiej.

53 Międzynarodowa koncepcja ALM - assets and liabilities management zob. A. Sheng, Y.J. Cho, Risk management and stable financial structure for LDC, Inc., [w:] G. Caprio, P. Honohan, D.Vittas (red.), Financial Sector Policy for Developing Countries: A Reader, Nowy Jork 2002, s. 49-72. K. Marchewka-Bartkowiak, prezentując wyniki badań międzynarodowych w obszarze zarządzania długiem publicznym, wskazuje, że w ujęciu bilansowym w zależności od krajowych rozwiązań uwzględnia się aktywa budżetowe, czyli obecną wartość przyszłych podatków, aktywa finansowe, czyli udziały w przedsiębiorstwach państwowych, aktywa rzeczowe wartość majątku państwowego, jak również rezerwy walutowe banku centralnego. Po stronie pasywów wliczane są zobowiązania z tytułu zadłużenia konwencjonalnego i potencjalnego. Szerzej: K. Marchewka-Bartkowiak, Zarzq̨dzanie długiem Skarbu Państwa. Implikacje dla strefy euro, Warszawa 2011, s. 29. 
tucjonalnej. Jawi się bowiem uzasadnione pytanie, jakimi instrumentami dysponuje Minister Finansów w ramach zarządzania aktywami i pasywami finansowymi. Należy więc zwrócić uwagę, że de facto tak skonstruowana norma kompetencyjna wymaga odpowiedniego doboru, ale także i pomiaru poszczególnych kategorii bilansowych, czyli wielkości ekonomicznych, w tym sensie pozostawia Ministrowi Finansów znaczną elastyczność. Taka konstatacja jest uprawniona także, jeśli za punkt odniesienia przyjąć Strategię, do której odsyła ustawa w ramach realizowanych przez Ministra działań w zarządzaniu pasywami i aktywa$\mathrm{mi}^{54}$. Z prawnego punktu widzenia należałoby postulować bardziej precyzyjne uregulowanie omawianego zagadnienia. W obecnym kształcie można twierdzić, że to Minister Finansów dookreśla, jakie instrumenty wykorzystuje, a brak normatywnego ich uszczegółowienia sprawia, że działania te pozostają poza kontrolą tak społeczną, jak instytucjonalną ${ }^{55}$.

\section{Wnioski}

Kompetencje Ministra Finansów związane z przyjmowaniem od jednostek sektora finansów publicznych wolnych środków w depozyt lub zarządzanie stanowią płaszczyznę aktywności tego organu uwypuklającą istotną rolę w zarządzaniu długiem Skarbu Państwa. Jak wskazywano w niniejszym opracowaniu, ten stosunkowo nowy, aczkolwiek dynamicznie rozwijający się instrument pozwala Ministrowi Finansów na istotne oddziaływanie na jednostki sektora finansów publicznych, w szczególności na te, które są zobligowane do dokonywania tego rodzaju lokat. Instrument ten daje Ministrowi Finansów możliwość wykorzystywania aktywów finansowych jednostek sektora finansów publicznych, a przez to prowadzi

54 Por. Pismo Dyrektora Departamentu Długu Publicznego z dnia 17 marca 2014 r., sygn. DP2/ 657/9/LCH/60/14/RD - 25884, niepublikowane.

55 Zwrócić uwagę należy, że w sprawozdaniach z wykonania ustawy budżetowej brak szczegółowych danych związanych z zarządzaniem aktywami i pasywami. Zob. Sprawozdania z wykonania ustawy budżetowej za lata 2012-2017 opubl. https://mfarch2.mf.gov.pl/ministerstwo-finansow/dzialalnosc/finanse-publiczne/budzet-panstwa/ wykonanie-budzetu-panstwa/sprawozdanie-z-wykonania-budzetu-panstwa-roczne (dostęp: 24.04.2019 r.). 
do zmniejszenia uzależnienia sektora publicznego od zdobywania środków na rynku i jest jednym z głównych sposobów obniżania kosztów i ryzyka budżetowego, prowadzących do obniżenia poziomu pożyczkowych potrzeb budżetu państwa. Zwrócić uwagę należy na niejednolite położenie prawne Ministra Finansów względem jednostek dokonujących lokat wolnych środków. Występując w imieniu Skarbu Państwa, Minister kształtuje treść stosunków prawnych albo na płaszczyźnie prywatnoprawnej dominium, albo w sposób władczy w ramach imperium. Nie ulega przy tym wątpliwości, że środki przyjęte w depozyt i zarządzanie stanowią z punktu widzenia Ministra bardzo użyteczny instrument w zarządzaniu płynnością długu Skarbu Państwa, które odznacza się elastycznością stosowanych przez Ministra środków.

Szczególne położenie Ministra Finansów obejmuje operacje zarządzania wolnymi środkami budżetu państwa oraz zarządzanie aktywami finansowymi i pasywami finansowymi. Przeprowadzona analiza pozwala na konstatację, że normatywne ujęcie uprawnień Ministra Finansów w powyższym zakresie odznacza się znaczną dyskrecjonalnością, przejawiającą się w możliwości podejmowania elastycznych działań i swobodzie w doborze konkretnych instrumentów prawnych służących zarządzaniu. Stan taki jest wynikiem zastosowania niedookreślonych normatywnie zwrotów: wolnych środków budżetowych, lokowania na rynku finansowym, zarządzenia pasywami czy zarządzania aktywami, których znaczenie jest bardzo szerokie, a jednocześnie ich transpozycja z języka ekonomicznego na prawny - utrudniona. O ile taki stan elastycznego działania znajduje wytłumaczenie na gruncie ekonomicznym, jako że w praktyce realizacja kompetencji przez Ministra Finansów wymaga odpowiedniego doboru i pomiaru poszczególnych wielkości ekonomicznych, o tyle z prawnego punktu widzenia kwestia niedookreśloności pojęć odnoszących się do prawnie dopuszczalnych działań Ministra Finansów rodzi wątpliwości natury instytucjonalnej, gdyż taki stan nastręcza trudności w ustaleniu ich rzeczywistego katalogu, a co za tym idzie ich legalności. Wydaje się więc, że przyznanie Ministrowi Finansów władztwa, którego przejawem jest dyskrecjonalność w doborze instrumentów wykorzystywanych do zarządzania długiem Skarbu Państwa, jest nieodzowne, bo- 
wiem działania te są uzależnione od dynamicznie zachodzących zmian na rynkach finansowych. Minister Finansów, bazując na pogłębionych pracach analitycznych podległych mu komórek organizacyjnych Ministerstwa (tzw. ministerialny model zarządzania), powinien mieć możliwość sprawnego reagowania na te zmiany. Stąd wysuwanie postulatów o ograniczenie tej elastyczności w praktyce może okazać się nieuzasadnione. Jednocześnie elastyczność działalności Ministra Finansów uzasadniona ekonomicznie jest niełatwa do usprawiedliwienia na płaszczyźnie prawnej, gdyż może stwarzać ryzyko pozostawania tej często skomplikowanej działalności poza kontrolą społeczną i instytucjonalną.

\section{Bibliografia:}

Bożek W., Depozyt u Ministra Finansów - stan obecny i przyszłe zmiany [w:] E. Kowalewska, P. Mańczyk (red.), Współczesne problemy bankowości i sektora finansów publicznych, tom I, Uniwersytet Szczeciński, Wydział Prawa i Administracji, Szczecin 2015.

Drwiłło A., Maśniak D. (red.), Leksykon prawa finansowego. 100 podstawowych pojęć, Wydawnictwo C.H. Beck, Warszawa 2009.

Głuchowski J., Lokaty budżetowe [w:] M. Weralski (red.), System instytucji prawno-finansowych PRL, t. II, Instytucje budżetowe, Zakład Narodowy im. Ossolińskich, Wrocław-Warszawa-Kraków-Gdańsk-Łódź 1982.

Głuchowski J., Lokaty budżetowe w Polsce, Państwowe Wydawnictwo Naukowe. Oddział Poznań, Toruń 1968.

Jurkowska-Zeidler A., Publicznoprawne formy oddziaływania państwa i Unii Europejskiej na instytucje kredytowe i finansowe, [w:] J. Głuchowski (red.), System prawa finansowego. Prawo walutowe. Prawo dewizowe. Prawo rynku finansowego, t. IV, Wolters Kluwer Polska, Warszawa 2010.

Karlikowska M., W. Miemiec, Z. Ofiarski, K. Sawicka, Ustawa o finansach publicznych, Presscom, Wrocław 2010.

Kosikowski C., Nowa ustawa o finansach publicznych. Komentarz, LexisNexis Polska, Warszawa 2010.

Lipiec-Warzecha L., Ustawa o finansach publicznych. Komentarz, Warszawa 2011, ABC a Wolters Kluwer business, el/LEX.

Marchewka-Bartkowiak K., Skonsolidowany system zarzqdzania płynnościq sektora publicznego, „Analizy Sejmowe BAS” 2010, nr 19, s. 1-7. 
Marchewka-Bartkowiak K., Zarzq̨dzanie długiem Skarbu Państwa. Implikacje dla strefy euro, Difin, Warszawa 2011.

Misiąg W. (red.), Ustawa o finansach publicznych. Ustawa o odpowiedzialności za naruszenie dyscypliny finansów publicznych. Komentarz, Wydawnictwo C.H. Beck, Warszawa 2019.

Ofiarski Z. (red.), Ustawa o finansach publicznych. Komentarz, Wolters Kluwer Polska, Warszawa 2019, SIP LEX/El.

Rutkowska-Tomaszewska E., Lokowanie wolnych środków przez jednostki samorzq̨du terytorialnego w bankach, „Finanse Komunalne” 2012, nr 4, s. 25-32.

Sheng A., Cho Y.J., Risk management and stable financial structure for LDC, Inc. [w:] G. Caprio, P. Honohan, D.Vittas (red.), Financial Sector Policy for Developing Countries: A Reader, World Bank Publications, Nowy Jork 2002, s. 49-72.

Smoleń P. (red.), Ustawa o finansach publicznych, Wydawnictwo C.H. Beck, Warszawa 2014.

Wymeersch E., The future of financial regulation and supervision in Europe. „Common Market Law Review” 2005, nr 4, s. 987-1010.

Zapadka P., Aspekty prawne funkcjonowania rynku finansowego w Polsce, „Bank i Kredyt” 2002, nr 1, s. 28-43. 